\title{
Entre la retórica y la ruta: la relación patrimonio y turismo cultural en la carta de ICOMOS $^{1}$
}

\author{
Giselle Virginia Chang-Vargas* \\ Universidad de Costa Rica (Costa Rica)
}

\begin{abstract}
Resumen: La relación patrimonio y turismo es un dilema. El estudio de cada uno de estos elementos por aparte es algo complejo, pero, el estudio de ambos en un mismo paquete es un gran reto. Para analizar esta relación, se toma como base la Carta del Turismo y Patrimonio de ICOMOS, organismo cuya misión es conservar el patrimonio cultural. Figuran también como texto (en el sentido semiótico y etnográfico) algunas observaciones de estudio o vivencias de distintas situaciones de Costa Rica o de otros países, que se interpretan como discursos. Estos casos se incluyen como ejemplo para ilustrar hechos concretos ya sean de oportunidad, armonía y respeto, o de su contrario: amenaza, riesgo y depredación. Los proyectos sostenibles en ambos aspectos son una utopía, pues es difícil servir a "dos señores", por lo que a fin de cuentas se debe escoger y dar prioridad a los intereses de uno u otro.
\end{abstract}

Palabras Clave: Patrimonio; Turismo; Amenaza; Utopía; Contradicciones; Sostenibilidad.

\section{Between Discourse and Practice: Heritage and Cultural Tourism in the ICOMOS Charter}

Abstract: The relationship between heritage and tourism is problematic and intricate, not permitting a separate study of either of the interrelated elements. However, the relationship and analysis of the same is even more complex. This paper analyses how the links are discussed in the ICOMOS Charter of Tourism and Heritage. ICOMOS is an organization designed to preserve cultural heritage. We examine the text as discourse (in the semiotic sense) with observations and experiences from Costa Rica and other countries. These are included to illustrate cases either of opportunity, harmony and respect, or of threat, risk and depredation. However, projects that are sustainable in both aspects (heritage preservation and tourism) are a utopia. It is hard to serve "two masters", and ultimately one must choose and prioritize the interests of one over the other.

Keywords: Heritage; Tourism; Threats; Utopia; Contradictions; Sustainability.

\section{Introducción}

Este trabajo se enfoca en la relación que existe entre dos grandes fenómenos: el patrimonio cultural y el turismo, donde el proceso de mundialización representa una amenaza para el primero, por la tendencia a homogeneizar culturas, mientras que para el segundo es una oportunidad de desarrollo en distintos ámbitos y escenarios geo-socio-culturales.

No es nuestra intención profundizar en los conceptos de patrimonio y de turismo. No obstante, debido a ciertas confusiones sobre lo patrimonial, se anotan algunos puntos básicos sobre su alcance. Partimos de la premisa que el patrimonio cultural -concebido como una herencia y construcción histórica colectiva de bienes que son referentes identitarios de una comunidad-es un fenómeno dinámico, que se adapta a las nuevas condiciones del contexto. El patrimonio es una construcción histórica antigua, que se cifra en la selección que hace un grupo de elementos culturales materiales e inmateriales pues les otorga valores especiales y los concibe como bienes representativos de la cultura propia, que se deben proteger y transmitir de una generación a otra. El turismo es un fenómeno relativamente más reciente y, a pesar de la globalización, todavía no ha sido una vivencia de todos los pueblos del mundo.

Universidad de Costa Rica; E-mail: giselle.chang@ucr.ac.cr 
$\mathrm{Al}$ revisar documentos de divulgación cultural es común la mención a ambos, que se aproxima a un tipo de relación semántica que se denomina "colocación"2. Pero, el acercamiento a esta pareja (patrimonio/ turismo) no es nada sencillo. El estudio de esta relación es complejo, pues muchas variables intervienen en su conceptualización y desarrollo. Por lo tanto, la aproximación a ella es un reto, tanto para quienes se abocan a la investigación del fenómeno turístico y a la gestión del patrimonio cultural material e intangible, como a quienes se encargan del planeamiento y desarrollo de la actividad turística. Ya en los años finiseculares, en la Conferencia Mundial para el Turismo Sostenible se reconoció

“... que el turismo es una actividad ambivalente, dado que puede aportar grandes ventajas en el ámbito socioeconómico y cultural, mientras que al mismo tiempo contribuye a la degradación medioambiental y a la pérdida de la identidad local, por lo que debe ser abordado desde una perspectiva global" (CMTS, 1995:3).

El objetivo de este trabajo es reflexionar en torno a las relaciones que se establecen entre el patrimonio cultural y el turismo, en cualesquiera de sus modalidades. La intención ${ }^{3}$ es compartir algunas de las inquietudes surgidas en la tarea de investigar ambos fenómenos, desde la antropología y los estudios culturales. Es vox populli $i^{4}$ que hay un trecho entre los patrones de comportamiento reales e ideales y eso, más bien ha sido un motivo para intercambiar opiniones sobre las razones de esta fractura, que a veces es ligera y en otros casos, más distante o profunda.

Es abundante la literatura ${ }^{5}$ sobre investigaciones que tratan esta relación, a lo que se agregan las memorias $^{6}$ de congresos sobre patrimonio, donde no falta una mesa de trabajo que directa o indirectamente trate los efectos del turismo y con base en las experiencias que se presentan, se distinguen partidarios y detractores, se señalan las contradicciones y ambigüedades del turismo. Con el propósito de evitar maniqueísmos, intentaremos confrontar y conciliar diferentes puntos de vista, en aras de contribuir al debate del tema con argumentos basados en la observación de la realidad, como algunas gestiones y proyectos comunitarios o gubernamentales asociados con el patrimonio cultural y el turismo. Reiteramos la complejidad de estudiar esta relación, en parte por la misma polisemia sobre los conceptos, la variedad de los fenómenos (ecoturismo, turismo cultural, etnoturismo, turismo de masas, entre otros, y su relación con el patrimonio intangible, los monumentos históricos, los paisajes culturales, los museos arqueológicos, etc.). En este tema es embrolloso aislar la mirada de turista y la de antropóloga estudiosa del turismo.

\section{Metodología}

A escala internacional, la doctrina en este campo es bastante amplia, pues hay una considerable cantidad de fuentes escritas, cifradas en convenios y declaraciones internacionales. Entre los principales documentos en materia de turismo están la Declaración de Manila sobre el Turismo Mundial, la Declaración de La Haya y la Carta del Turismo y Código del Turista. En materia de patrimonio, la UNESCO ha aprobado en sus asambleas generales y reuniones técnicas varias declaraciones: Convención para la Protección de los Bienes Culturales en Caso de Conflicto Armado (1954), Convención sobre las medidas que deben adoptarse para prohibir e impedir la importación, exportación y transferencia de propiedad ilícitas de bienes culturales (1970), Convención sobre el Patrimonio Mundial Natural y Cultural (1972), Convención sobre la Protección del Patrimonio Cultural Subacuático (2001), la Convención para la Salvaguarda del Patrimonio Cultural Inmaterial (2003); Convención sobre la Protección y Promoción de la Diversidad de las Expresiones Culturales (2005). Este organismo también ha emitido declaraciones en este campo, como la Recomendación sobre la salvaguardia de los bienes culturales muebles (1978) y las recomendaciones sobre la salvaguarda de la cultura popular y tradicional (1989), sobre el paisaje urbano histórico (2011); la relativa a la protección del patrimonio documental (2015 y la recomendación relativa a la protección y promoción de los museos y colecciones, su diversidad y su función en la sociedad. Si se incluyen los tratados y convenios referentes a las variadas dimensiones del desarrollo ${ }^{7}$, se incrementa el material, que ha sido la base para la formulación de políticas que vinculan el trinomio patrimonio, turismo y desarrollo.

Para analizar esta relación - a veces de matrimonio armonioso y otras de divorcio convencido- se toma un documento emanado del Consejo Internacional de Sitios y Monumentos: la "Carta8 Internacional del Turismo Cultural". La gestión del turismo en los sitios con patrimonio cultural significativo que alude a varias normas y recomendaciones de otras Cartas Internacionales, emanadas por ese organismo. 
Se utiliza el análisis de contenido como técnica, complementaria con el cotejo de la observación directa y la observación participante (Taylor y Bogdan, 1987: 31-94), ambas son técnicas del método etnográfico, comunes en la investigación cualitativa, que se aplicaron a estudios e informes sobre turismo cultural realizados en Costa Rica y otros países centroamericanos. Hay diferentes tipos de análisis de contenido (entre ellos: semiótico, léxico, estructural, ideológico, análisis crítico del discurso, psicoanalítico), pero en este caso es pertinente la investigación semiótica, concebida como "el estudio de la producción, circulación e interpretación del sentido en contextos enunciativos determinados" (Abril, 1999:429). Con esta autora, se comparte que esta es una metodología para la interpretación de textos-discursos y hasta de comportamientos, pues las acciones humanas se conciben en un sentido amplio como textos, lo que se ejemplifica con algunos casos que ilustran o registran hechos concretos de amenaza, riesgo, depredación o armonía. El análisis del discurso es una lectura de los signos, que por su carácter polisémico ha sido objeto de diferentes interpretaciones, por lo que la base de la rigurosidad es conocer el contexto ${ }^{9}$ en que se inserta el mensaje. Este análisis se puede aplicar a todo tipo de textos (verbales: escritos y orales, no verbales: visuales, gestuales, artefácticos, etc.).

Escogimos esta modalidad de análisis, pues permite su aplicación a investigaciones complejas, como a estudios más cortos o en proceso, pues nos permite realizar inferencias que tengan validez y confiabilidad con base en el contexto determinado en que se producen. No obstante, para su aplicación debemos advertir la necesidad del conocimiento del contexto histórico o contar con datos e información sobre aspectos económicos, políticos y ambientales de esa sociedad. Seguimos varios pasos como identificar una situación dada, que fue el texto escrito, visual, gestual u oral que registramos en nuestras notas de campo. Comparamos los mensajes de esos textos con enunciados de la Carta sobre Turismo y Patrimonio de ICOMOS (Consejo Internacional de Monumentos y Sitios, por sus siglas en inglés). La tarea fue un ejercicio de interpretación, para lo que fue relevante el conocimiento o información previa sobre el lugar. Este paso se enfocó en la identificación y clasificación del mensaje, según su claridad, intenciones ocultas o explicitas, en fin, descifrar las prácticas discursivas, cifradas en expresiones, gestos, comportamientos, actitudes y valores en torno al binomio patrimonio-turismo. La unidad de análisis fue la oferta turística-cultural, es decir, los bienes patrimoniales utilizados como recursos turísticos. Las categorías incluyeron el territorio, la infraestructura, los bienes culturales materiales e inmateriales, así como textos legales. Las unidades de análisis, donde aplicamos técnicas etnográficas fueron los sitios naturales y culturales, las tradiciones, los museos, los festivales y el marco legal.

El motivo por el cual se toma como base el análisis de ciertos enunciados de la Carta del Turismo Cultural, de ICOMOS (1999) se debe a que ese organismo tiene el estatus de asesor de UNESCO en materia de patrimonio cultural, así que sus recomendaciones inciden en la formulación de políticas, reforzadas con sus asociaciones ${ }^{10}$ en todos los continentes. Sin embargo, a pesar de las buenas intenciones de los documentos de marcar una ruta a seguir, es frecuente hallar un trecho de incongruencias entre diversos postulados emanados de los comités técnicos, aprobados en asambleas generales y las prácticas discursivas concretas.

\section{Temas analizados en el estudio de la Carta}

La Carta se compone de una introducción y seis principios (de los que presentamos una sinopsis), subdivididos en acápites específicos. De los cuatro objetivos, uno de ellos se refiere a "facilitar y animar el diálogo entre los intereses de la conservación del patrimonio y los intereses de la industria del turismo", ya que han predominado acciones separadas sobre tópicos comunes.

El principio 1 señala que "desde que el turismo nacional e internacional se ha convertido en uno de los más importantes vehículos para el intercambio cultural, su conservación debería proporcionar oportunidades responsables y bien gestionadas a los integrantes de la comunidad anfitriona, así como proporcionar a los visitantes la experimentación y comprensión inmediatas de la cultura y el patrimonio de esa comunidad" (ICOMOS, 1999:3).

El principio 2 dice que "la relación entre los sitios con patrimonio y turismo es una relación dinámica y puede implicar valoraciones encontradas. Esta relación debería gestionarse de modo sostenible para la actual y futuras generaciones" (ICOMOS,1999:3).

El principio 3 apunta que "La planificación de la conservación del patrimonio y del turismo en los sitios con patrimonio, debería garantizar que la experiencia del visitante le merezca la pena y le sea satisfactoria y agradable" (ICOMOS, 1999:4). 
El Principio 4 estipula que "Las comunidades anfitrionas y los pueblos indígenas deberían involucrarse en la planificación de la conservación del Patrimonio y en la planificación del Turismo" (ICOMOS, 1999:5).

El principio 5 se refiere a que "Las actividades del Turismo y de la conservación del Patrimonio deberían beneficiar a la comunidad anfitriona" (ICOMOS, 1999:5)

El principio 6 señala que "los programas de promoción del turismo deberían proteger y ensalzar las características del patrimonio natural y cultural" (ICOMOS, 1999:6).

\subsection{El respeto al patrimonio en la gestión del turismo}

En la introducción, la Carta de ICOMOS se refiere al espíritu del documento, a la amplitud de los entornos naturales y culturales que abarca el concepto de patrimonio, y al derecho de su conservación, pues "constituye la esencia de muy diversas identidades nacionales, regionales, locales, indígenas y es parte integrante de la vida moderna" (ICOMOS, 1999:1) y en tiempos de globalización es un desafío su conservación. Se apunta que el acceso bien gestionado a los bienes del patrimonio es un privilegio que

"conlleva la responsabilidad de respetar los valores del patrimonio natural o cultural, así como los intereses y patrimonios de la actual comunidad anfitriona, de los pueblos indígenas conservadores de su patrimonio o de los poseedores de propiedades históricas, así como la obligación de respetar los paisajes y las culturas a partir de las cuales se ha desarrollado el Patrimonio" (ICOMOS, 1999:1)

En la Carta se señala que el turismo "es un factor esencial para muchas economías nacionales y regionales y puede ser un importante factor de desarrollo cuando se gestiona adecuadamente" (ICOMOS, 1999:2). Coincidimos en el papel del turismo como fuente de divisas a distintas escalas, así como en su rol potencial de favorecer el desarrollo, condicionado por el estilo de gestión. En ese sentido, es obvia la conveniencia de esa alianza, pues los fondos captados por el turismo, son de provecho para generar o aumentar el capital económico y cultural de una comunidad, pues estos se reinvierten en la educación formal. Cabe mencionar el caso del pueblo indígena brunca -ubicado en los territorios Boruca y Curré, en el sureste de Costa Rica-, donde a inicios de los 70, solo dos jóvenes tuvieron la oportunidad de ser becados y realizar estudios en el liceo y la Universidad de Costa Rica, donde estudiaron Agronomía y hoy (gracias a la venta de sus artesanías al turismo), la gran mayoría de la niñez y la juventud local logra terminar sus estudios primarios y secundarios y cada año, al menos un miembro de ese pueblo, se gradúa en alguna de las universidades del país. En ese caso se observa que "el espacio de las posiciones sociales se retraduce en un espacio de tomas de posición por intermedio de los habitus" (Bourdieu, 2010:31), es decir, del producto de los condicionamientos sociales, cuya modificación se dio ante el incremento de un nuevo capital, facilitado por el auge del turismo. Hay muchos casos de cómo el flujo de turistas nacionales contribuye a sostener la economía familiar en zonas agrícolas, pero el dato no está registrado (pues en el censo, el oficio familiar se consigna como agricultor u oficios domésticos), cuando su tiempo lo dedican a cultivar hortalizas y frutas, preparar panes y otros productos caseros, que venden por donde transitan turistas. Esto es común en todas las zonas rurales de Costa Rica y las orillas de las principales autopistas.

Es fundamental distinguir entre las modalidades de turismo y sus intereses, pues los resultados de un proyecto tendrán efectos diversos, como menciona la Carta:

"el Turismo excesivo o mal gestionado con cortedad de miras, así como el turismo considerado como simple crecimiento, pueden poner en peligro la naturaleza física del Patrimonio natural y cultural, su integridad y sus características identificativas. El entorno ecológico, la cultura y los estilos de vida de las comunidades anfitrionas, se pueden degradar al mismo tiempo que la propia experiencia del visitante" (ICOMOS, 1999:2).

Es importante recordar que hay tipos de turismo y de turistas, así que no se debe copiar un modelo que funcionó con éxito en un lugar y aplicarlo en otro contexto. En Costa Rica, ante el auge del ecoturismo, para solucionar la situación de pobreza de muchos poblados, es común que surjan proyectos con ofertas turísticas en zonas con bellos paisajes naturales, esperando un resultado similar al desarrollo de Guanacaste y el Pacífico Central, lamentablemente, esas propuestas a menudo son riesgosas para la población del lugar, los visitantes y el medio ambiente, ya que no toman en cuenta diferencias de clima, relieve y falta de infraestructura. A esto se agrega la idealización del auge de esos polos turísticos -donde hay mayor flujo de iniciativas inmobiliarias externas, en un contexto con limitadas capacidades públicas para planificar, identificar y mitigar los riesgos ante las irregularidades en la aprobación de planes 
reguladores, con los efectos en manejar la demanda de agua para riego, la producción y manejo de los desechos y el cambio en el uso del suelo (cfr. Programa Estado de la Nación, 2007).

\subsection{Turismo e intercambio cultural}

En el principio 1 se menciona que "Desde que el turismo nacional e internacional se ha convertido en uno de los más importantes vehículos para el intercambio cultural, su conservación debería proporcionar oportunidades responsables y bien gestionadas" (ICOMOS, 1999:3).

Aunque concordamos con la última oración del párrafo, cuestionamos el uso generalizado del término "intercambio cultural", pues no explicita que hay diferentes modalidades y enfoques que generan distintos comportamientos en un intercambio determinado. Al revisar la historia de la humanidad, se observa que en las diversas formas de contacto entre pueblos con culturas diferentes, aunque por lo general se realiza un paso de rasgos de una cultura a la otra, este intercambio no siempre se ha efectuado en un marco de equidad y respeto, ni de relaciones dialógicas. Es pertinente apuntar un concepto que explica esta situación con el aporte del etnólogo cubano Fernando Ortiz, quien en el año 1939 acuñó el concepto de "transculturación" (Ortiz, 1983:90) ${ }^{11}$. Si bien el debate sobre el contacto con la otredad es parte del quehacer antropológico y se ha enriquecido con nuevos aportes, como la corriente de filosofía intercultural, cuyo ideólogo Raúl Fornet-Betancourt (2013) reconoce la visión de Ortiz y la vigencia de su propuesta en la interpretación de las fases del contacto.

El término intercultural es amplio y en la variedad de relaciones que admite, hay buenas y malas experiencias. En el ámbito de la lengua, es evidente que esta cumple un rol esencial, por lo que G. Dann (1996) se refiere a un "lenguaje del turismo", tanto por el mensaje implícito en los vocablos como por el uso de la jerga turística. Por ejemplo, el inglés cumple una función de lingua franca, como se observa su uso predominante en rótulos de aeropuertos, el chek-in y el chek-out en los hoteles, entre otros. La voz francesa tour, es uno de los vocablos más frecuentes en la actividad turística. Hoy es común notar la transferencia y mezcla de códigos lingüísticos hasta en pequeñas aldeas rurales y/o indígenas, como cuando una artesana le dice al turista "handicrafts a 100 pesos"; o cuando el turista regresa a su país con nuevo vocabulario: poncho, chumpa, choclo, palta, guacamole, gallo, tortilla, guaro o cachaça, caipirinha, pinga, etc., que denotan la variedad geosocial de la lengua española y la diversidad léxica del portugués brasileño para distintos tipos de aguardiente de caña de azúcar. Estos ejemplos, muestran la veta de aprendizaje informal que facilita el turismo.

Sin embargo, hay intercambios culturales que se valen del turismo para generar prácticas que son consideradas negativas por la mayoría de la población (a excepción de quienes obtienen beneficio de ellas o todavía no reconocen los riesgos), como el incremento del turismo sexual en comunidades costeras latinoamericanas - portadoras de una diversidad de bienes culturales y naturales de valor patrimonial- como sucede en algunos poblados de las costas Caribe y Pacífico costarricense, que se promocionan por Internet o en brochures turísticos (cfr. Frohlick, 2008:8-19). Los riesgos de contactos con "ciertos visitantes" 12 se basan en hechos observados y testimonios de población local, pero la llamada sociedad en riesgo global "no hay mejor abono para los riesgos que el negarlos" (Beck, 2000:15), pues como dice Beck, ante un espectro de posibilidades y un déficit de conocimiento, es casi imposible definir con certidumbre el nivel exacto de los riesgos. El turismo sexual es un comportamiento cultural que superó la fase de encuentros sexuales entre nativos y visitantes, pues en la actualidad esta actividad trae consigo la adquisición de otras prácticas como el abuso infantil, la prostitución juvenil, trata de blancas, el alcoholismo y no solo el consumo, sino la compra o alquiler de casas y yates, que son punto de distribución de drogas, pues estas zonas costeras se utilizan como puente para el narcotráfico (cfr. La Nación, mayo, 2017). Estas actividades generan violencia (como el sicariato contra extranjeros y nacionales, "peces gordos o flacos") en detrimento de las tradiciones de paz y los valores morales de la cultura local.

\subsection{El patrimonio como recurso turístico}

No hay duda del dinamismo de la interacción entre el turismo y el patrimonio, pues este es uno de los mayores atractivos y recursos para el turismo. Esta identificación es un elemento que el mercado exige al gestor de destinos turísticos, pues -entre las tendencias de la oferta, los nuevos productos y el reposicionamiento de productos consolidados- se menciona la "inserción de aspectos culturales, ambientales y del patrimonio histórico en la oferta turística (Vignati-Scarpati,2009:81) y entre las tendencias de la demanda se incluye "la valoración del turismo étnico social, del turismo sostenible, del turismo responsable y solidario" (Vignati-Scarpati, 2009:82). 
Varios estudiosos del patrimonio y de la cultura (Vargas y Sanoja, 1993; Prats, 2004; Yúdice, 2006; Ballart y Treserras, 2008), se han referido a la noción de recurso cultural y recurso turístico, lo que es parte del debate en el campo de la economía de la cultura. El cambio de sentido de bien a recurso cultural, nos remite a la cuestión del uso del patrimonio, que plantea tres escenarios diferentes: 1) el patrimonio para sí, para ser disfrutado y vivido por y dentro de la comunidad que lo heredó y lo custodia; 2) el patrimonio para los otros, es decir, como recurso turístico adecuado a proyectos de turismo, lo que se presta, como apunta Llorenç Prats (2004:43), a una triple casuística ${ }^{13}$; y, 3) una mezcla de ambos. Tras la simple palabra 'recurso', se encuentra el engendro de situaciones complejas. Al respecto se transcribe la opinión del Banco Mundial ${ }^{14}$ :

"El patrimonio genera valor. Parte de nuestro desafío conjunto es analizar los retornos locales y nacionales para inversiones que restauran y derivan valor del patrimonio cultural, trátese de edificios y monumentos o de la expresión cultural viva como la música, el teatro y las artesanías indígenas" (citado en Yúdice, 2009:16).

A pesar de su poder, la figura y el rol de ese organismo financiero han sido cuestionado por reconocidos cientistas sociales (Hinkelammert, 2007; Ibisate,1998) y algunos gobiernos latinoamericanos ${ }^{15}$ pues no es necesario ser economistas para observar que tras su misión de "promover la prosperidad compartida de manera sostenible" (Banco Mundial), aprovecha para tener injerencia en las políticas públicas de los países latinoamericanos; es ingenuo pensar que ese poderoso Banco es un samaritano y que sus intereses se orientan a fomentar los derechos culturales de los pueblos a desarrollar y conservar su patrimonio. Una lectura connotativa de su gestión, constata lo que el antropólogo Lombardi Satriani (1978:91), hace varias décadas llamó "cultura de la ganancia", por la habilidad en apropiarse de la ideología de lo genuino de un pueblo. En este sentido, se debe estar alerta acerca de cuál es el fin prioritario de que el patrimonio sirva de recurso para el turismo, si predomina fortalecer el negocio o los valores identitarios inherentes a lo patrimonial.

\subsection{Valoraciones encontradas}

El principio 2, alude a las valoraciones encontradas que pueden presentarse en los sitios con patrimonio y turismo. Este punto de la Carta es el que amerita mayor reflexión, por lo que se hace referencia a cada acápite, aunque se transcriben solo algunas frases.

\subsubsection{Desarrollo, límites y sostenibilidad}

En el punto 2.1, se hace un llamado a las instituciones gubernamentales

"La protección y conservación a largo plazo de las culturas vivas, de los sitios con Patrimonio, de sus variados objetos, de su integridad física y ecológica y de su contexto medioambiental, debería ser un componente esencial en el desarrollo de las políticas sociales, económicas, políticas, culturales y turísticas (ICOMOS, 1999:4).

En la relación patrimonio/turismo es fundamental la formulación y ejecución de lineamientos, pero se enfatiza que sean sólidos y claros. Sin embargo, hay casos donde se contraponen las acciones de instituciones públicas: en un inventario ${ }^{16}$ cultural realizado en el cantón de Santa Cruz de Guanacaste, se registraron comidas y bebidas que identifican a la región, que tanto nacionales como extranjeros las valoran como recurso turístico. En un contexto amenazado por la demanda de fast food, la gestión de organizaciones comunales como CoopeTortillas y Sol Verde, en pro de la gastronomía tradicional y orgánica, fue reconocida por el Ministerio de Cultura al incluirlos en la Galería de la Cultura Popular Tradicional, incentivo que avala acciones complementarias en pro de otras áreas del patrimonio. Desde hace varias décadas, en esa zona hay una amenaza urgente para la sostenibilidad del patrimonio y del turismo: la dificultad por salvaguardar la producción de cerámica chorotega -declarada patrimonio inmaterial de la Península de Nicoya-estimada como recurso de gran demanda turística y fuente de ingresos para la mayoría de las familias alfareras. La causa del riesgo es que el terreno donde está la veta de barro desde hace varios años está en manos privadas, pues aunque en los años 40, la antropóloga Doris Stone lo compró y donó a la comunidad artesana, pero, durante la guerra civil de 1948 se quemaron los archivos municipales y desde la década de los 90, los nuevos dueños prohibieron el paso y se limitan a vender algunos kilos de materia prima a un alto costo para las familias alfareras. En el 2014, cambió el propietario, pero la negociación continúa y el problema no se ha resuelto para los artesanos. Hasta 
tanto el gobierno nacional y local no tomen medidas que permitan la devolución de la única veta de barro, la continuidad de esa ancestral producción está en peligro.

El punto 2.2 es contradictorio pues apunta que

"Los proyectos turísticos, sus actividades y su desarrollo, deberían conseguir resultados positivos y minimizar los impactos negativos para el Patrimonio y para los modos de vida de la comunidad anfitriona, al mismo tiempo que deberían responder a las necesidades y expectativas del visitante" (ICOMOS, 1999.4).

El estilo de la mayoría de las convenciones y declaratorias internacionales es algo retórico, pues el mensaje se cifra en la buena intención, para persuadir a los gestores que se identifiquen en poner en práctica esta Carta. Además, no siempre hay convergencia entre las necesidades del visitante y los intereses de las comunidades y en este punto, volvemos a llamar la atención a los tipos de turistas y turismo. Las tipologías son muy variadas, tal como lo sistematiza el antropólogo español Agustín Santana (1998, 27-32), y muchas de ellas tienen comportamientos opuestos, algunos muestran respeto a la otredad, mientras que otros se sienten amos y señores, que exigen pleitesía por pagar un servicio.

Brevemente, mencionamos un caso en Costa Rica: El primer polo de vacaciones del país fue Puntarenas -desde mediados del siglo XIX- puerto del Pacífico Central, donde las familias del Valle Central iban a veranear y disfrutar de otras costumbres (comidas, bebidas, canciones y artesanías) típicas de la zona. A partir de los 90, con el auge del turismo, llegan cruceros con grupos de visitantes extranjeros, lo que introdujo el turismo sexual, que abrió espacios para que muchos turistas se comporten irrespetuosamente en sitios públicos y con personas que no ofrecen ese servicio. Esta afirmación se basa en observaciones ${ }^{17}$ en el "Paseo de los Turistas", calle peatonal junto a la playa, donde hay muchas heladerías, cafeterías y venta de souvenirs y, se corrobora con relatos de meseras de restaurantes del lugar, que son acosadas por algunos turistas.

Costa Rica se ha convertido en uno de los destinos más frecuentes a escala mundial en materia de turismo sexual, ante debilidades de programas públicos y que no es ilegal ejercer la prostitución, amenaza contra los valores y la sostenibilidad de la actividad turística, por lo que se creó el Programa "Protegiéndoles" (cfr. http://cactustour.com/index.php?id=85\&L=1), al que se han afiliado empresas vinculadas con el turismo (operadores turísticos, restaurantes, transportes) y organizaciones no gubernamentales con proyectos por la población infantil y juvenil. Este programa se rige por un "Código de Conducta para la Protección de Niñas, Niños y Adolescentes contra la Explotación Sexual Comercial en Viajes y Turismo", que firman las entidades que se comprometen a combatir estas prácticas negativas.

\subsubsection{Conocer y valorar el significado del patrimonio}

En el acápite 2.3 se expone que los programas de desarrollo turístico deberían basarse en un entendimiento diáfano de los aspectos significativos del patrimonio sobre todo en sitios complejos y conflictivos, por lo que "es importante la continua investigación y el asesoramiento para lograr una permanente comprensión y aprecio de estos significados" (ICOMOS, 1999:4).

Se considera que esta acción es más conveniente en zonas de turismo étnico, pues las diferencias culturales y el sentido de sus tradiciones a menudo es desconocido por los intermediarios del turismo, lo que afecta negativamente a los turistas (pues pierden la oportunidad de valorar aspectos reales de la otredad cultural) y a las comunidades receptoras (por las ventajas económicas del turismo, reciben mecánicamente a grupos de visitantes, cuya mirada se desarticula del verdadero sentido de los bienes).

Hay casos positivos en que los guías turísticos están certificados no solo por la institución rectora del turismo en el país o una cámara de turismo regional, sino por entidades especializadas en el estudio del patrimonio de los pueblos y de su diversidad cultural, como el Instituto de Antropología e Historia, como se observa en México, Argentina, Perú, Guatemala o hay controles de organizaciones de los mismo pueblos que son visitados, como el caso del Consejo de Cultura de Gunayala, en Panamá. En estos casos se brinda al turista información sobre el contexto histórico-cultural y la situación de un determinado pueblo indígena y su relación con las políticas gubernamentales, por lo que la experiencia es de beneficio para ambas partes: comunidad receptora y visitantes. En Costa Rica, el turismo cultural es relativamente reciente y el Instituto Costarricense de Turismo (ICT) otorga Certificado de Sostenibilidad Social, pero todavía no hay indicadores oficiales para estimar la sostenibilidad cultural, aunque haya organizaciones de guías turísticos, la formación de estos procede de distintas instituciones y muchas carecen de material didáctico que enseñe sobre los bienes culturales y su significado. Por lo tanto, todavía es común que se presenten casos como el que observamos ${ }^{18}$ en Sierpe -pequeño poblado del sur costarricense, ubicado entre canales y manglares, cerca de ciertos poblados indígenas- donde algunos jóvenes locales trabajan 
como guías turísticos (sin certificación), entre ignorancia de las prácticas y sentidos, así como de buscar a atraer a los turistas, relatan a los turistas otra versión de las tradiciones indígenas, al comunicar una serie de imágenes fantasiosas, como afirmar que las esferas de piedra del Diquis fueron traídas por extraterrestres; atribuir a otras especies animales el color del tinte morado que se obtiene del caracol múrice; inventar "historias" sobre el origen o celebración del juego de los diablitos del pueblo brunca. Esta "inocente" tergiversación de bienes emblemáticos de un pueblo, engatusa a los turistas, falta a la ética y fomenta la turistización de la cultura. Este caso avala la vigencia de lo señalado por Llorenç Prats (2003:131), al apuntar la diferencia referirse a "las disciplinas que se ocupan respectivamente del patrimonio y el turismo son distintas y estancas".

El desconocimiento de los significados del patrimonio cultural y del contexto en que funcionan sus bienes trae como consecuencia una serie de carencias informativas y de posibilidades de comunicación entre los actores del turismo. Por ejemplo, desde la óptica de muchos tour-operadores y otras entidades, los indígenas o pueblos originarios que conservan sus tradiciones son "perdedores" y pasan a ser "exitosos" al aceptar administrar los casinos que el Estado ha promovido en los desiertos de Arizona y Nuevo México, ubicados en zonas cercanas a la mayoría de reservas indígenas de Estados Unidos. Este fue el mensaje emitido por un guía turístico no indígena, a grupos de turistas y estudiosos de la actividad en esa pluriétnica región.

Este caso nos enfrenta al problema de los valores, pues desde una mirada superficial, los visitantes observan las grandiosas edificaciones en medio desierto, donde miles de personas juegan fortunas millonarias y aunque los navajos y otros pueblos indígenas reparten las ganancias del casino en su pueblo, la mirada profunda (aquella que interpreta la complejidad de otra visión del mundo), halla nuevos problemas (alcoholismo, violencia doméstica, obesidad ante el cambio de dieta), generados por el cambio de patrones culturales, que refuerzan la reproducción de una imagen negativa de los indígenas y limitan el valor cultural de estos pueblos en sus artes populares (Bright \& Bakewell, 1995), que han posicionado como objeto de estima en mercados y festivales internacionales.

\subsubsection{Autenticidad o exotismo en la oferta turística}

El punto 2.4, se refiere a un asunto muy álgido en materia de estudios de las identidades y los valores del patrimonio cultural, que ya ha sido tratado en otros documentos de ICOMOS, como la Carta de Venecia (1964), que se refiere a las intervenciones para conservar sitios y monumentos histórico-arquitectónicos ${ }^{19}$ y la Carta de Nara (1994), que al reconocer la diversidad de culturas y de patrimonios, concibe la autenticidad como relativa al tipo de bien y a los valores que en cada época le atribuyen al patrimonio. Un lustro después, la Carta de 1999 continúa indicando la importancia de

"conservar la autenticidad de los sitios del patrimonio y de la variedad de sus objetos. La autenticidad constituye un elemento esencial del significado cultural...Los programas deberían presentar e interpretar la autenticidad de los sitios y de sus experiencias culturales para mejorar el aprecio y la comprensión del patrimonio cultural" (ICOMOS, 1999: 4).

El concepto de "auténtico" ha sido estudiado por muchos investigadores del patrimonio cultural y de la historia del arte, aunque no hay coincidencia en sus enfoques, las distintas perspectivas son aportes para el debate en el marco de la Carta. Por ejemplo, es una demanda turística y el turismo crea escenografías (MacCannell, 1976); se ajusta a los requerimientos de turistas y anfitriones (Boorstin, 1991); es una construcción social (Cohen, 1988); puede ser negociable, varía según la demanda (Cohen,1988; Taylor, 2001); es una ficción (Augé, 1998); es una conexión entre objeto turístico y vivencia (Wang, 1999); los turistas son los receptores de la autenticidad (Chabra, 2005). Sin embargo, un punto común es concebir la autenticidad como un atributo dinámico, en cuya interpretación predomina lo subjetivo, por lo que ante la pregunta ¿qué es lo auténtico de un sitio y de un objeto?, se hallan matices según el tipo de bien patrimonial. En el caso de bienes materiales o tangibles, la clave está en que los materiales y diseños fueran genuinos u originales, al momento de su construcción. Respecto a los bienes intangibles, cuestionamos la autenticidad si esta no se vincula con la identidad cultural de la comunidad portadora que vela por su salvaguarda. En este ensayo, partimos de la premisa de que lo auténtico está en riesgo desde el momento en que hay una transformación de los valores de uso por valores de cambio y, esto sucede (tarde o temprano, según el contexto) con la llegada del turismo, que trae consigo el fomento de pautas de consumo en distinta escala, hasta llegar a extremos de consumismo y mercantilización cultural. Como dice J. A. Donaire (2012:136) "el turismo es una forma de semiótica, es decir, una forma de interpretar unos símbolos determinados", que impregna las relaciones sociales. Al ser la actividad 
turística una forma de romper con la cotidianeidad, de manera anticipada al viaje se crean símbolos turísticos, por medio de imaginarios. En este aspecto nos encontramos con problemas éticos, como lo referimos en casos en que los intermediarios promueven la compra de un objeto o la visita a un sitio y embaucan a los turistas.

En el caso de las artesanías, una manera de garantizar un poco que un artefacto fue hecho en un determinado lugar y reconocer la autoría, para así proteger la propiedad intelectual del grupo creador es mediante la llamada "denominación de origen". Decimos "un poco", pues la amenaza de la copia se mantiene. La oferta de lo auténtico implica una suerte de juego entre los actores del turismo, pues, parafraseando a R. Amirou (1995:336) se valen del exotismo, como una ilusión útil, que reduce los significados de un destino turístico a un par de características. Es común que se asocie lo indígena con ranchos y máscaras; el Caribe con palmeras y sexo; lo brasileño con el carnaval y el fútbol, pues esas imágenes estereotipadas se venden como atracciones de un "paquete". Pero, no debemos confundir la proyección y representación de una tradición que se vende como exótica, con la vivencia real por el grupo portador de esa tradición. Es el caso de las llamadas "limpias" de cuerpo o espíritu que ofrecen algunas personas dizque curanderos, suquias o sacerdotes, al aprovecharse de la ingenuidad de turistas que buscan lo exótico (Cfr. Chang, 2014) y les ofrecen "el ritual de sus sueños" con una ceremonia o espectáculo inventado, en el que usan elementos (humo, incienso, aguardiente, ramos de hojas, rancho o paraje especial en un río o bosque) que son un remedo de tratamientos aplicados por personas reconocidas en una colectividad. Este tipo de actividad es calificada como falsa por la población nativa o local, que no acude a ese tipo de consultas para foráneos.

Un indicio para estimar lo auténtico se da cuando los miembros de un grupo diferencian entre el uso y sentido de un objeto o una práctica cotidiana y otra que se usa para los turistas. Sin embargo, se deben evitar los juicios de valor sobre la autenticidad, pues como apuntaron en el documento de Nara, no hay que basarse en criterios fijos, sino en fuentes de información confiables, sustentadas en el contexto histórico y legitimadas por la colectividad a la que pertenece. Aunque haya acuerdo que la autenticidad de una expresión cultural es avalada por la comunidad portadora, la situación a veces es más compleja, como en el caso ${ }^{20}$ de la representación cultural con variantes, una más apegada a la tradición y otra más abierta a la innovación, con motivos más exóticos.

\subsubsection{El contexto del sitio patrimonial y la coherencia de la infraestructura turística}

En el acápite 2.5, se hace un llamado para que en la infraestructura de los proyectos para el desarrollo turístico se tome en cuenta "la dimensión social, estética y cultural, los paisajes naturales y culturales, las características de su biodiversidad, así como los amplios contextos visuales de los sitios con Patrimonio" (ICOMOS, 1999:4).

El respeto al contexto en que se halla un bien cultural es fundamental en las declaratorias patrimoniales, no solo en las de índole material. Se debe atender la armonía entre el entorno ambiental con las edificaciones y otras prácticas humanas. El contexto económico-político de Centro América, como se señala en el IV Informe Estado de la Región (cfr. Estado de la Región, Cap.1 2011:362) sin llegar a extremos de crisis como en los 80, si retrocedió en los frentes ambientales, económicos, políticos, oscila entre limitaciones financieras e imposiciones de los gobernantes y, por falta de visión o por intereses ajenos a la conservación del patrimonio y sostenibilidad turística, otorgan licitaciones subjetivamente, impulsan proyectos con materiales ajenos a las tradiciones culturales o no amigables con el ambiente. En la última década, el ICOMOS de Costa Rica ha debido enfrentarse a proyectos que atentan la conservación del patrimonio histórico-arquitectónico. En 2010, los propietarios demolieron una casona de adobe, construida en la primera mitad del siglo XIX, a pesar de ser patrimonio declarado y el interés de la comunidad por comprarlo para construir un centro cultural (http://www.nacion.com/ocio/artes/ Patrimonio-denunciara-demolicion-casona_0_1123087802.html). Un caso reciente, es el de otra sede para la Asamblea Legislativa, en una construcción de 17 pisos, que romperá la armonía con el entorno histórico urbano y el aval de la construcción fue dado por la instancia del Ministerio de Cultura y el de los y las diputados (http://www.icomoscr.org/content/index.php?option=com_content\&view=article $\& \mathrm{id}=320$ : asamblea\&catid=49:defensas\&Itemid=84). Otros proyectos remodelación de inmuebles como el Teatro Variedades y el Hotel Costa Rica (http://www.nacion.com/vivir/arquitectura/Remodelacion-Gran-Hotel-Costa-Rica_0_1638036268.html); están en estudio judicial y restauración arquitectónica y aún no se sabe en qué terminarán las negociaciones.

Un ejemplo positivo es Antigua Guatemala, donde hay logros a pesar de la presión por incrementar las grandes edificaciones por la visita de miles de turistas. Allí se prohíben las intervenciones que atenten el diseño colonial del centro histórico la ciudad (por ej., las empresas transnacionales de comidas rápidas 
no pueden imponer su logotipo ni otro estilo en la fachada), así como las edificaciones de varios pisos, cuya altura impida apreciar la vista del Volcán de Agua.

\subsubsection{El impacto sobre el patrimonio y los límites al turismo}

El punto 2.6, refuerza el punto anterior y se enfoca en la necesidad de poner límites.

"Antes de que un creciente turismo promueva o desarrolle sitios con Patrimonio, los planes de gestión deberían sopesar los valores naturales y culturales de estos recursos.../ Si el previsible nivel de cambio es inaceptable, deberían modificarse los planes de desarrollo que se propongan” (ICOMOS: 1999:4).

En lugares pequeños también puede haber depredación, pero es difícil estimarla. Sin embargo, en sitios famosos ${ }^{21}$ hay más atención al respecto, pues al ser reconocidos mundialmente, si no se guardan las medidas para su conservación, se corre el riesgo de perder la declaratoria. Se exhorta para que los planes de desarrollo contemplen los eventuales impactos sobre el territorio, el ambiente, el bienestar social y la cultura de la llamada comunidad huésped o "anfitriona", término acuñado por la antropóloga Valene Smith (1979), para referirse a la comunidad receptora de turistas.

El impacto connota choque o golpe fuerte y para evitarlo, todo plan de desarrollo turístico, debería tomar medidas ${ }^{22}$ previas a la ejecución. Cabe aludir a otros ejemplos en Costa Rica: uno positivo, pues con el fin de conservar el sitio, se prohíbe a los turistas caminar sobre las calzadas del Monumento Arqueológico Guayabo de Turrialba y, otro negativo. Este último se refiere a eventuales megaproyectos en la zona del Diquis, donde se ubican los asentamientos indígenas con esferas de piedra, que la UNESCO declaró, en el 2014, como Patrimonio de la Humanidad ${ }^{23}$ y, también rica zona de humedales. Sin embargo, hay graves amenazas contra ese patrimonio cultural y natural, pues desde hace varios años hay un megaproyecto hidroeléctrico; desde el 2012, se promueve la construcción de un aeropuerto internacional y en el 2017, la ampliación del cultivo de piña, que colinda con estos sitios, también reconocidos por su paisaje cultural. El gobierno que avale estos proyectos, quedará en la historia como el padrino de la depredación del patrimonio (cfr. Estudio Multidisciplinario: aproximaciones al megaproyecto hidroeléctrico el Diquís). http://kioscosambientales.ucr.ac.cr/documentos/EstudioDiquis.pdf.

Las comunidades portadoras de patrimonio y receptoras de turismo pueden ocupar un papel activo, pero, si falta conciencia acerca de los valores patrimoniales, se impone la recepción de mensajes confusos desde la oficialidad y la voz comunal se puede replegar ante atractivas promesas.

\subsubsection{Necesidad del seguimiento de los bienes patrimoniales}

El punto 2.7, señala que "Deberían elaborarse programas de evaluación continua para valorar los impactos progresivos de las actividades turísticas y de los planes de desarrollo en cada sitio o comunidad" (ICOMOS: 1999:4). Esto es lo ideal, pero algo alejado de las prácticas usuales, pues es común argüir que hay limitaciones financieras para esa tarea. Aunque haya quejas sobre casos perjudiciales, se impone el laissez passer, por evitar conflicto ante eventuales alianzas entre empresarios y autoridades gubernamentales. Pocas personas se atreven a denunciar intereses que atentan contra el patrimonio natural o cultural, pues debido al poder de grandes empresas, su queja se invisibiliza. En 1995, la UNESCO declaró la Tradición del Boyeo y la Carreta de Costa Rica "Obra Maestra del Patrimonio Oral e Intangible de la Humanidad", pero existen ${ }^{24}$ carencias en el monitoreo del plan de acción y la coordinación entre las organizaciones boyeras, las municipalidades y el gobierno central, por lo que persisten problemas con los cuatreros, que matan las yuntas de bueyes, ante la impunidad de la policía rural; las normativas municipales que limitan los desfiles de boyeros, yuntas y carretas en zonas urbanas; los altos costos del flete y traslado de carretas y yuntas, desde zonas alejadas al lugar de un evento, entre otras y hay varios cantones del Valle Central, otrora región de auge, donde la tradición está en riesgo (cfr. Chang, 2017).

\section{Planificación de la oferta al turista}

El principio 3 se enfoca en la oferta al turista: debe tener contenidos de calidad para que pueda disfrutar de la visita al haber obtenido información sobre las características de un lugar y lo significativo del patrimonio y así comportarse respetuosamente con comunidad que se visita. En el punto 3.2, se apunta la necesidad de que los visitantes experimenten los sitios patrimoniales a su propio ritmo. Este punto es compatible con los derechos humanos y culturales y en varios países han implementado facilidades para 
el acceso a personas con alguna discapacidad. Lamentablemente, la mayoría de las agencias carecen de una oferta adecuada a los requerimientos del turista y mientras abundan los paquetes con itinerarios con trayectos largos y cansados, al llegar al destino, se debe seguir al guía en una carrera estrepitosa. Surge la pregunta: ¿por qué si hay operadoras de turismo masivo, que diariamente inician un tour de 5, 8, 12 o 15 días, no ofrecen paquetes ajustados a otros intereses? En este caso, los cruceros se acercan a una oferta diversa, pues en un día de navegación hay múltiples opciones para disfrutar. En Costa Rica, gracias a la Ley $\mathrm{N}^{\circ} 7600$ sobre accesibilidad, es obligatorio construir rampas o ascensores en sitios públicos. Esta medida es costosa y no se puede aplicar en todo lugar, pues si es sitio patrimonial debe respetar la integridad y armonía con el entorno, según lo estipulan otras leyes (cfr. Ley $\left.\mathrm{N}^{\circ} 7555\right)$.

\section{Participación de las comunidades y pueblos indígenas}

El principio 4 de la Carta se refiere al tema del compromiso y la participación, palabras usuales en el discurso, pero, aunque las acciones para su logro deberían ser imperativas, es algo muy difícil de realizar. Las causas de las limitaciones se hallan en la ignorancia del proceso histórico y las vicisitudes sufridas por los pueblos sometidos a procesos de conquista y colonización que deterioraron las relaciones sociales.

Getino (2002:80) explica que a partir del auge del turismo "todo aquello ${ }^{25}$ a lo cual no se le había dado hasta entonces ningún valor, parecía comenzar a tenerlo con la aparición del mercado de la oferta y demanda turística". Son pocas las organizaciones o comunidades indígenas del continente que tienen la posibilidad de planificar el tipo de desarrollo que consideran adecuado para la conservación de sus tradiciones y a la vez, disfrutar diversas ventajas de la mundialización. En Costa Rica, por lo general, se trata de micro o pequeñas empresas familiares o comunales, que complementan su proyecto turístico con otras actividades. Es el caso de proyectos ${ }^{26}$ de los pueblos indígenas ${ }^{27}$, en los que se hallan orientaciones diferentes, algunas codependientes de entidades foráneas y otras con mayor claridad y control en su programa de actividades.

El punto 4.1, específicamente hace alusión al respeto de los derechos e intereses de la comunidad anfitriona, ya sea que esta opere a nivel local, regional o se trate de pueblos indígenas, que

"deberían involucrarse en el proceso de establecer objetivos, estrategias, políticas y métodos para la identificación, conservación, gestión, presentación e interpretación de sus propios recursos patrimoniales, de sus prácticas culturales y de sus actuales expresiones culturales, dentro del contexto turístico" (ICOMOS, 1999:5).

Este principio es clave para la solución de la mayoría de los problemas que se generan en la relación patrimonio-turismo, pero el camino al logro está lleno de señales confusas, que ameritan respeto a la otredad y participación real en las distintas fases del proceso. ${ }^{28}$

Cuestionamos la visión de la comunidad "anfitriona" como una unidad monolítica, pues en la realidad concreta, esta es una comunidad receptora de turistas, compuesta por distintos sectores sociales con enfoques particulares y hasta antagónicos. Ante esto, los foráneos deberían respetar cuál es la instancia legitimada según los lineamientos internos de una comunidad determinada. Lamentablemente, hay intervenciones de intermediarios que toman partido (para evitar que sus intereses se afecten "negativamente" o porque "ayudaron" en algún proyecto comunal), con lo que el conflicto se agrava.

La inserción de entidades foráneas en una comunidad es algo que merece cuidado y respeto. No debe reducirse o confundirse con acciones informativas, muchas veces de tipo indirecto. Con frecuencia los canales informativos no son nítidos y ante esta falta de transparencia, es poco probable que la opinión comunal sea sólida. Este vicio o práctica ha sido común en los megaproyectos hidroeléctricos, que crean alianzas con los de índole turística y ofrecen la fórmula para saltar hacia un desarrollo sin precedentes.

Otro es el caso de la toma de un rol activo, por las comunidades afectadas ante un eventual proyecto. El pueblo indígena térraba (teribe o brorán) se opone a una represa en la zona del Diquís, proyecto todavía latente -que amenaza con inundar sitios espirituales, arqueológicos y la biodiversidad regional, gracias al maridaje de entidades públicas costarricenses y privadas que convergen en una concepción limitada de desarrollo- que antepone el avance tecnológico al respeto de la consulta ${ }^{29}$ con los pueblos afectados y la integridad de los bienes patrimoniales (cfr. el estudio interdisciplinario realizado en la UCR: www. http://kioscosambientales.ucr.ac.cr/documentos/EstudioDiquis.pdf.). 


\section{Control en la cantidad y calidad en el acceso a sitios patrimoniales}

El punto 4.2 se refiere a la necesidad de limitar el acceso a ciertos bienes de reconocimiento mundial

Cuando el Patrimonio de un sitio o región concretos pueda tener una dimensión universal, deberían respetarse las necesidades y los deseos de las diversas comunidades o pueblos indígenas para restringir o administrar la región y el acceso físico, espiritual o intelectual a determinadas prácticas culturales, conocimientos, creencias, actividades, objetos o lugares (ICOMOS, 1999:5).

Es el caso de sitios (pirámides y templos mayas e incas, egipcios, muralla china, etc.) expuestos tanto al deterioro de fenómenos naturales, como al paso de miles de visitantes. En el Perú, con el fin de evitar la erosión aplican controles, como el cierre temporal o limitar el acceso a Macchu Picchu y a Huayna Picchu. Esto afecta las entradas de las agencias operadoras de turismo, pero ante la magnitud del evento, se ha impuesto la normativa conservacionista, que en los sitios de patrimonio mundial, también es monitoreada por UNESCO.

Un atractivo actual es "maquillar" los sitios patrimoniales o su entorno, donde "el espacio de la simulación es el de la confusión de lo real y del modelo. Ya no hay distancia crítica y especulativa de lo real a lo racional... lo real es hiperrealizado" con la "transfiguración en el mismo lugar, aquí y ahora, de lo real en modelo..." (Baudrillard, 2012:189). En el sitio arqueológico del Tajín, en Veracruz, México hay investigaciones antropológicas (Zúñiga, 2013, 2014), que muestran la preocupación por una tendencia al estilo Disney del sitio, ya que el turismo es considerado como motor del desarrollo de la región, pero ,como apunta Zúñiga (2012: 2012:259) el gobierno estatal se ha encargado de elaborar discursos e imágenes idílicas de la cultura totonaca, que se ofrecen como objeto de consumo turístico y parafraseando a Baudrillard (2012: 117), el público visitante se resiste a la comunicación con sentido y lo que piden es espectáculo ${ }^{30}$.

\section{Equidad en los beneficios}

El Principio 5 se compone de seis acápites que se enfocan en la distribución equitativa de los beneficios del turismo, cuestión que debe provocar desde carcajadas a una sonrisa disimulada de parte de muchos empresarios que han invertido su capital en un proyecto de desarrollo turístico. Una empresa puede ser sostenible en el aspecto turístico, pero no hay garantía que lo sea en los costes no solo financieros, sino en el aprovechamiento de los recursos humanos, culturales y ambientales de un destino. Así funcionan algunos operadores y proveedores de turismo, que convierten la actividad en un arma a su favor, pues como señalan Cañada y Gascón (2007: 28) "puede obligar a la comunidad a acatar ciertas condiciones, so pena de encaminar a los turistas hacia otras zonas con una oferta similar. O promover la competencia a la baja, entre comunidades de la región, de las que solo él saldría beneficiado".

La Carta sugiere que los legisladores promuevan medidas para lograr la equidad, pero ya hay experiencias negativas sobre cómo se "cocinan" las leyes en la mayoría de los parlamentos y cámaras de diputados. En Costa Rica el marco legal asociado al turismo es numeroso (cfr. Revista Parlamentaria, 2005), que inicia en 1955 con la ley que crea el Instituto Costarricense de Turismo ICT y a la fecha cuenta con tres decenas de leyes y varios proyectos de ley; decenas de proyectos archivados; otros de convenios y acuerdos con diversos países; varias resoluciones en la Sala Constitucional. No obstante, los instrumentos legales no siempre favorecen los proyectos de microempresarios y son los grandes complejos turísticos, los que gozan de las múltiples prerrogativas del sistema, desde la exoneración de impuestos, usurpación de caminos públicos, concesiones del usufructo de un territorio por 99 años, entre otras.

Otro punto de este principio, se enfoca en la formación de intérpretes y guías de turismo provenientes de la misma zona, necesidad que además abre espacios a la población local, heredera de un cúmulo de bienes. Su logro requiere otro tipo de alianzas, en este caso entre los programas de turismo y las entidades educativas. Las experiencias de capacitación o formación ${ }^{31}$ en América Latina, son muy diversas. 


\section{Protección del patrimonio cultural}

El Principio 6 apela a la producción de expectativas reales de los potenciales visitantes y reitera puntos como promover el patrimonio y proteger la autenticidad; vender recuerdos locales para asegurar que no se degrade la integridad cultural. Este conjunto de buenas intenciones es muy difícil de controlar, pues si no hay convergencia de intereses, se trata de una lucha entre David y Goliath y, la meta es ganar gracias al dominio de recursos tecnológicos, ofertas más competitivas, aunque no funcionen en un marco con límites. Además, se explota el uso de imágenes publicitarias, recurso que lleva al éxito económico, aunque el precio sea la depredación de tradiciones de valor patrimonial. El tema de los souvenirs -trofeos de viaje, como diría Canestrini (2001)- amerita un estudio particular, pues su barato costo productivo, puede tener un alto costo en la reproducción de estereotipos y la venta de imágenes de un pasado que no corresponde a la dinámica cultural.

\section{Conclusiones}

La dificultad de analizar la relación entre el patrimonio cultural y el turismo es muy compleja, pues implica conocer el rol de factores multisectoriales implícitos en ese nexo.

No podemos afirmar que la existencia de espacios para acciones de reciprocidad es una señal de augurio en el nexo armonioso y sustentable entre ambos fenómenos socioculturales. Tampoco podemos dictar sentencia sobre la misión imposible de amarrar un lazo diáfano y congruente entre el discurso y las prácticas. Cuando se amplía la oferta turística con atractivos del patrimonio cultural, se abren nuevos nichos que incrementan la demanda de turistas interesados en temas de memoria histórica, tradiciones e identidad. Mientras que el desarrollo de ciertas modalidades de turismo, como el masivo y el etnoturismo, pueden traer efectos negativos sobre el patrimonio de un pueblo, como lo señalan múltiples estudios (cfr. Barretto, 2007; Quintero, 2004; Salazar: 2006, 2010, entre otros), ya que hay condicionamientos de distinta índole más allá de las buenas intenciones de un programa turístico.

La relación "patrimonio y turismo" nos remite a diversos escenarios, según la coincidencia de intereses entre los diversos actores. No se trata de formular una relación dicotómica, "matrimonio o divorcio", entre ambos, sino de distinguir una gama de matices, una suerte de continuum entre la convergencia o divergencia de intereses, así como en la jerarquización de prioridades y definición de los actores que controlan sus bienes o recursos culturales de interés turístico.

El turismo es una oportunidad para abrir espacios físicos y sociales de intercambio cultural, orientados en descubrir y valorar el patrimonio de la otredad, gestión que debe basarse en un proceso educativo de sensibilización al grupo de actores y agentes del patrimonio y el turismo. Lamentablemente, las prácticas priorizan aspectos de marketing y minimizan aspectos sustantivos sobre el conocimiento de las culturas locales.

El dinamismo es una característica de todo fenómeno sociocultural, por lo que hay que mantener una información actualizada y profesional del contexto en el que se realiza un proyecto. Si bien la cuestión de la sostenibilidad es un punto crucial y eje de múltiples proyectos, se considera que es algo utópico, pues sí hay algunos proyectos sostenibles en lo turístico, pero con debilidades o amenazas en el componente patrimonial. Tras la consulta de artículos y el relato de experiencias exitosas, estas últimas se dan en situaciones en pequeña escala y los resultados son moderados.

Las posibilidades de éxito en proyectos turísticos culturales en un marco de desarrollo sostenible requieren de la participación activa de la comunidad, pues ellas deben ser las protagonistas en la transmisión y salvaguarda de su patrimonio, de acuerdo al sentido que otorgan a sus bienes patrimoniales. Las comunidades portadoras de patrimonio y receptoras de turismo no siempre están en condiciones de asumir un rol activo, pues hay factores inhibitorios, como la carencia de información de distintas fuentes, lo que facilita la confusión ante las pautas publicitarias y discursos oficiales con promesas atractivas; las discrepancias entre grupos internos, entre otras. Por ejemplo, en Centro América ha habido oposición popular a las represas hidroeléctricas, pero la actitud y comportamiento ante otros proyectos (canales y aeropuertos cerca de sitios patrimoniales) es contradictoria.

Una necesidad de todo tipo de proyecto es definir su alcance y fijar los límites. Los sitios patrimoniales que gozan de declaratorias universales tienen mayor esperanza de recibir apoyo de diversas entidades para su conservación. Las iniciativas pequeñas, como las de turismo rural comunitario surgieron aproximadamente en el segundo lustro del siglo XXI, todavía no han desarrollado herramientas para consolidar el ámbito de lo propio y romper algunos elementos de codependencia con entidades auspiciadoras. 
Por supuesto en todo hay excepciones, como el caso del pueblo totonaca de Veracruz, México, cuyo Centro de las Artes Indígenas recibió de la UNESCO (2012) la mención de "Buena práctica de salvaguardia del patrimonio cultural inmaterial". Al preguntar a uno de los líderes totonacas acerca de su secreto, respondió: "priorizar y nosotros decidimos consolidar nuestra identidad cultural y hasta después, permitimos la llegada de turistas, pero siempre con límites" (CAIT.2013 . No obstante, otros proyectos cosifican el patrimonio, al montar un espectáculo full color en el vecino sitio arqueológico Tajín.

Es tiempo de dejar de insistir en la autenticidad y dedicar más atención a consolidar el sentido y valor de los bienes culturales para un pueblo. Paralelamente, es hora de abrir el paso a la participación real de las comunidades en la gestión de sus proyectos turístico-culturales, clave para la sostenibilidad de estos. Se trata de implementar políticas públicas que fomenten el diálogo y alianzas tripartitas (Comunidades/Estado-nación/Empresa Turística), que co-gestionen proyectos de puesta en valor de los bienes patrimoniales, pero asociados a los contextos y procesos de producción, transmisión, apropiación y consumo. Es decir, la estrategia es educar a actores y agentes del turismo en la proyección del patrimonio en un marco de respeto a sus creadores y portadores.

La Carta de ICOMOS es un marco de referencia para la reflexión y la esperanza de establecer lineamientos, que se plasmen en hechos concretos de compromiso y cooperación que permitan una relación de armonía entre el turismo y el patrimonio cultural. Ojalá surjan iniciativas que posibiliten su práctica.

\section{Bibliografia}

Abril, G.

1999. "Análisis semiótico del discurso". En: J.M. Delgado y J. Gutiérrez (Coordinadores). Métodos y técnicas de investigación en Ciencias Sociales. Madrid: Editorial Síntesis. Pp.427-463.

Amirou, R.

1995. Imaginaire touristique et sociabilités du voyage. Paris: Les Presses Universitaires de France Asamblea Legislativa.

2005. Desafíos de la actividad turística en el siglo XXI. Revista Parlamentaria. San José:vol13 (2).

Ballart, J. y J. Treserras

2008. Gestión del patrimonio cultural. Barcelona: Editorial Ariel.

Banco Mundial

http://www.bancomundial.org/

Baudrillard, J.

2012. Cultura y simulacro. Barcelona: Editorial Kairós.

Barretto, M.

2007. Turismo y cultura. Relaciones, contradicciones, expectativas. Colección PASOS. Edita N 1.

Beck, U.

2000. "Retorno a la teoría de la sociedad del riesgo". En: Boletín A.G.E., №30, pág.9-20.

Boorstin, D.

1991. The Image: a Guide to Pseudo-Events in American. New York:Vintage.

Bourdieu, P.

2003. Capital cultural, escuela y espacio social. Argentina: Siglo XXI Editores.

Bright, J. y Bakewell, L.

1995. Looking High and Low. Art and Cultural Identity. Tucson: The University of Arizona Press.

Canestrini, D.

2001. Trofei di viaggio. Per un'antropologia del souvenir. Torino. Bollati Boringhieri.

Cañada, E. y J. Gascón.

2006. Turismo y desarrollo: herramientas para una mirada crítica. Managua: Fundación Luciérnaga. Chambers, E.

2000. Native tours. The anthropology of travel and tourism. Prospect Heights, Illinois: Waveland Press. Chang Vargas, G.

2017. "La tradición del boyeo y la carreta como patrimonio mundial: percepción y estado actual".

En: Simposio Valores y riesgos en torno al patrimonio cultural. XI Congreso Centroamericano de

Antropología. Red Centroamericana de Antropología. San José: UCR. 
Chang Vargas, G.

2014. "Turismo étnico: sus trampas en algunos casos de comunidades indígenas de Costa Rica". Pp. 393-422. En: Turismo cultural: retos y perspectivas en América Latina (Editores: Julián Oviedo y Edna Rozo), Universidad del Externado. Bogotá: Colombia.

Chang Vargas, G.

2014. Imaginarios Turísticos y transformaciones del patrimonio cultural indígena: artesanías y artes bruncas de 1975 a 2014. Tesis para optar al grado de Doctora en Estudios de la Sociedad y la Cultura. Sistema de Estudios de Posgrado, Universidad de Costa Rica.

Chang, G.

2012. El proyecto hidroeléctrico Diquis: la oferta turística en la región y el patrimonio intangible indígena del pueblo térraba. En: Estudio Multidisciplinario: aproximaciones al megaproyecto hidroeléctrico el Diquís. Pp 156-181. http://kioscosambientales.ucr.ac.cr/documentos/EstudioDiquis.pdf.

Chhabra, D.

2005. Defining authenticity and its determinants: Toward an authenticity flow model. En: Journal of Travel Research, 44(1), 64-73.

Cohen, E.

1988. Authenticity and Commoditization in Tourism. En: Annals of Tourism Research, vol15, 371-386.

CMTS. Conferencia Mundial de Turismo Sostenible

1995. Carta Mundial del Turismo Sostenible. Lanzarote, Islas Canarias, España, del 27 al 28 de abril. http://insula.org/carturi.pdf.

www.turismo-sostenible.org/docs/Carta-del-Turismo-Sostenible.pdf

Dann, G.

1996. The Language of Tourism. A Sociolinguistic Perspective. USA: CAB International.

Donaire, J.A.

2012. Turismo cultural. Entre la experiencia y el ritual. Girona: Edicions Vitel-la.

Fornet-Betancourt, R.

2013. IX Congreso Internacional de Filosofía Intercultural. Universidad de Costa Rica. Conferencia inaugural y comunicación personal, San José.

Frohlick, S. 2008. "Negociating the public secrecy ofsexina transnational tourist town in Caribbean Costa Rica." Tourist Studies, pp. 8-19. http:// tou.sagepub.comcontent 8/1/19.

Getino, O.

2002. Turismo. Entre el ocio y el neg-ocio: identidad cultural y desarrollo económico para América Latina y el Mercosur. (No. 379.85). Ediciones Ciccus.

Hinkelammert, $\mathrm{H}$.

2007. El asalto a lpoder mundial y la violencia sagrada del imperio. San José, Costa Rica :DEI. http://www.pensamientocritico.info/index.php/libros/libros-de-franz-hinkelammert?download=18

Ibisate,F.J.

1998. Neoliberalismo y globalización. En: Revista ECA, (600). Recuperado de: http://www.uca.edu.sv/ publica/eca/600art1.html

ICOMOS.

1964. Carta de Venecia. Carta Internacional para la conservación y restauración de conjuntos histórico-artísticos. www.icomos.org/charters/venice_sp.pdf

ICOMOS.

1994. Documento de Nara sobre la autenticidad. En: http://www.esicomos.org/Nueva_carpeta/info_ DOC_NARAesp.htm

ICOMOS.

1999. Carta Internacional del Turismo Cultural. La gestión del turismo en los sitios con patrimonio cultural significativo. www.patrimoniocultural.pt/.../cartaintsobreturismocu.

Lombardi Satriani, Luigi M.

1978. Apropiación y destrucción de la cultura de las clases subalternas. Buenos Aires: Editorial

Nueva Imagen.

MacCannell, D.

2007. Lugares de encuentros vacíos. Madrid: Melusina.

MacCannell, D.

1976. The Tourist: a New Theory of the Leisure Class. Los Angeles: California Press.

Ortiz, F.

1983. El contrapunteo cubano del tabaco y del azúcar. La Habana: Editorial de Ciencias Sociales. 
Prats, L.

2004. Antropología y Patrimonio. Barcelona: Ariel.

Programa Estado de la Nación.

2007. Decimotercer informe en Desarrollo humano sostenible. San José.

Quinteros Santos, J.L.

2004. "Impactos económico, socioculturales y medioambientales del turismo. En: Anales del Museo de América (12), pp.203-224.

Salazar, N.

2006. Antropología del Turismo en paises en desarrollo: análisis crítico de las culturas, poderes e identidades generados en el turismo. En: Tabula Rasa, $\mathrm{N}^{\circ} 55,99-128$.

Salazar, N.

2010. Envisioning Eden. Mobilizing Imaginaries in Tourism and Beyond. New York: Berghahn.

Santana Talavera, A.

1998. Antropología y turismo. Nuevas hordas, viejas culturas: Barcelona, Ariel Editores.

Self, W.

2014. Has English Heritage ruined Stonehenge? http://www.theguardian.com/books/2014/jun/21/from-heritage-to-heretics-stonehenge-making-history.

Smith, V.

1989. Hosts and Guests, The Anthropology of tourism. Philadelphia: University of Pensylvania Press. Taylor, J.P.

2001. Authenticity and Sincerity in Tourism. En: Annals of Tourism Research, 28 (1), .7-26.

Taylor, S. J. y R. Bogdan.

1987. Introducción a los métodos de investigación cualitativa. Buenos Aires, Paidós. 343 pp.

UNESCO

2003. Convención para la Salvaguardia del Patrimonio Cultural Inmaterial, Paris.

UNESCO

1972. Convención sobre la protección del Patrimonio Mundial, natural y cultural, Paris.

Vargas Arenas, I y M. Sanoja Obediente

1993. Historia, identidad y poder. Caracas. Fondo Editorial Tropykos.

Vignatti Scarpati, F.

2009. Gestión de Destinos turísticos, cómo atraer personas a polos, ciudades y países. México: Editorial Trillas.

Wang, N.

1999. Rethinking Authenticity in Tourism Experience. En: Annals of Tourism Research, 26 (2), 349-370

Yúdice, G.

2006. El recurso de la cultura. Usos de la cultura en la era global. La Habana: Editorial de Ciencias Sociales, Instituto Cubano del Libro.

Zúñigabravo, F.G.

2012. "El patrimonio biocultural frente a los procesos de apropiación turística y mercantilización como estrategia de desarrollo.para elTotonacapán veracruzano. En: Castellanos, ay Machuca, J.a.. (Coord). Turismo y Antropología: miradas del Sur y el Norte. México: Universidad Autónoma Metropolitana.

Zúñiga Bravo, F.G.

2013. "Los nuevos usos de la cultura y el patrimonio cultural en el contexto turístico de México. El caso del Totonacapan veracruzano". En: Oechemichen Bazán,C. (editora). 2013. Enfoques antropológicos sobre el turismo contemporáneo, México: UNAM.pp.193-242.

Zúñiga Bravo, F.G.

2014. "Los nuevos usos del patrimonio arqueológico del Tajín, Veracruz, a través de los procesos de turistificación, mercantilización y espectacularización”. En: Anales de Antropología, vol 48-II, UNAM. pp.151-184.

\section{Fuente Oral}

\section{CAIT}

2013. Miembro del Centro de las Artes indígenas totonacas. Conversación en el marco del XXXIII Symposio de ICOMOS de México,.Coaptepec, Estado de Veracruz. 


\section{Anexos}

http://www.nacion.com/sucesos/narcotrafico/

Noticias sobre narcotráfico en Costa Rica publicadas en La Nación. ... Actualizado el 23 de mayo de 2017. Asesinos novatos están detrás de crímenes narco.

Hombres en su gran mayoría jóvenes, pero inexpertos en el manejo de armas de fuego, son los que están detrás de los asesinatos que ocurren en el país.

Cárceles se llenan de imputados por narcotráfico. Las prisiones se están llenado de hombres y mujeres vinculados con asuntos de drogas.

Sucesos Pandillas reciben hasta $₫ 1$ millón diario en puntos de venta. Dominio sobre lucrativos búnkeres acelera guerra narco.

La venta al menudeo de "crack" y marihuana se convirtió en un negocio tan lucrativo, que controlar esos puntos de venta es la causa de buena parte de los asesinatos del país

http://cactustour.com/index.php?id=85\&L=1

Costa Rica es un país de respeto a los derechos humanos. ... Turismo ", el programa de lucha contra la explotación sexual asociada a los niños y adolescentes ...

http://archivo.eluniversal.com.mx/internacional/74344.html

19 Sep 2011 ... "Hemos tratado de quitar la imagen de Costa Rica como destino del turismo sexual", dijo en entrevista con El Universal, al explicar que las. Referencias Digitales

http://www.nacion.com/sucesos/narcotrafico/

Noticias sobre narcotráfico en Costa Rica publicadas en La Nación. ... Actualizado el 23 de mayo de 2017. Asesinos novatos están detrás de crímenes narco.

Hombres en su gran mayoría jóvenes, pero inexpertos en el manejo de armas de fuego, son los que están detrás de los asesinatos que ocurren en el país.

cárceles se llenan de imputados por narcotráfico. Las prisiones se están llenado de hombres y mujeres vinculados con asuntos de drogas.

Sucesos Pandillas reciben hasta $₫ 1$ millón diario en puntos de venta. Dominio sobre lucrativos búnkeres acelera guerra narco.

La venta al menudeo de "crack" y marihuana se convirtió en un negocio tan lucrativo, que controlar esos puntos de venta es la causa de buena parte de los asesinatos del país

http://cactustour.com/index.php?id=85\&L=1

Costa Rica es un país de respeto a los derechos humanos. ... Turismo ", el programa de lucha contra la explotación sexual asociada a los niños y adolescentes ...

http://archivo.eluniversal.com.mx/internacional/74344.html

19 Sep 2011 ... "Hemos tratado de quitar la imagen de Costa Rica como destino del turismo sexual", dijo en entrevista con El Universal, al explicar que las .

http://www.nacion.com/sucesos/narcotrafico/

Noticias sobre narcotráfico en Costa Rica publicadas en La Nación. ... Actualizado el 23 de mayo de 2017. Asesinos novatos están detrás de crímenes narco.

Hombres en su gran mayoría jóvenes, pero inexpertos en el manejo de armas de fuego, son los que están detrás de los asesinatos que ocurren en el país.

cárceles se llenan de imputados por narcotráfico. Las prisiones se están llenado de hombres y mujeres vinculados con asuntos de drogas.

Sucesos Pandillas reciben hasta $₫ 1$ millón diario en puntos de venta. Dominio sobre lucrativos búnkeres acelera guerra narco.

La venta al menudeo de "crack" y marihuana se convirtió en un negocio tan lucrativo, que controlar esos puntos de venta es la causa de buena parte de los asesinatos del país

http://cactustour.com/index.php?id=85\&L=1

Costa Rica es un país de respeto a los derechos humanos. ... Turismo ", el programa de lucha contra la explotación sexual asociada a los niños y adolescentes ...

http://archivo.eluniversal.com.mx/internacional/74344.html 
19 Sep 2011 ... "Hemos tratado de quitar la imagen de Costa Rica como destino del turismo sexual", dijo en entrevista con El Universal, al explicar que las.

http://www.nacion.com/sucesos/narcotrafico/

Noticias sobre narcotráfico en Costa Rica publicadas en La Nación. ... Actualizado el 23 de mayo de 2017. Asesinos novatos están detrás de crímenes narco.

Hombres en su gran mayoría jóvenes, pero inexpertos en el manejo de armas de fuego, son los que están detrás de los asesinatos que ocurren en el país.

cárceles se llenan de imputados por narcotráfico. Las prisiones se están llenado de hombres y mujeres vinculados con asuntos de drogas.

Sucesos Pandillas reciben hasta $\notin 1$ millón diario en puntos de venta. Dominio sobre lucrativos búnkeres acelera guerra narco.

La venta al menudeo de "crack" y marihuana se convirtió en un negocio tan lucrativo, que controlar esos puntos de venta es la causa de buena parte de los asesinatos del país

http://cactustour.com/index.php?id=85\&L=1

Costa Rica es un país de respeto a los derechos humanos. ... Turismo ", el programa de lucha contra la explotación sexual asociada a los niños y adolescentes ...

http://archivo.eluniversal.com.mx/internacional/74344.html

19 Sep 2011 ... "Hemos tratado de quitar la imagen de Costa Rica como destino del turismo sexual", dijo en entrevista con El Universal, al explicar que las .

http://www.nacion.com/sucesos/narcotrafico/

Noticias sobre narcotráfico en Costa Rica publicadas en La Nación. ... Actualizado el 23 de mayo de 2017. Asesinos novatos están detrás de crímenes narco.

Hombres en su gran mayoría jóvenes, pero inexpertos en el manejo de armas de fuego, son los que están detrás de los asesinatos que ocurren en el país.

cárceles se llenan de imputados por narcotráfico. Las prisiones se están llenado de hombres y mujeres vinculados con asuntos de drogas.

Sucesos Pandillas reciben hasta $\notin 1$ millón diario en puntos de venta. Dominio sobre lucrativos búnkeres acelera guerra narco.

La venta al menudeo de "crack" y marihuana se convirtió en un negocio tan lucrativo, que controlar esos puntos de venta es la causa de buena parte de los asesinatos del país

http://cactustour.com/index.php?id=85\&L=1

Costa Rica es un país de respeto a los derechos humanos. ... Turismo ", el programa de lucha contra la explotación sexual asociada a los niños y adolescentes ...

http://archivo.eluniversal.com.mx/internacional/74344.html

19 Sep 2011 ... "Hemos tratado de quitar la imagen de Costa Rica como destino del turismo sexual", dijo en entrevista con El Universal, al explicar que las .

http://cactustour.com/index.php?id=85\&L=1).

https://www.crhoy.com/.../informe-el-turismo-sexual-en-costa-rica-es-un-problema-gr...

2 ene. 2017 - El informe replicó algunos aspectos del turismo sexual en Costa Rica. Archivo CRH. "El turismo sexual infantil es un problema grave, ya que ...

https://actualidad.rt.com/sociedad/167060-costa-rica-turismo-sexual-narcotrafico

21 feb. 2015 - Más de 50.000 turistas sexuales visitan anualmente Costa Rica, un país donde las autoridades policiales luchan constantemente contra la ...

www.prensalibre.com/guatemala/solola/el-pais-es-un-paraiso-para-turismo-sexual

5 jun. 2016 - Añadió que el turismo sexual es una de las cuatro formas de explotación ... torturan y truncan vidas a costa del sufrimiento de otros", señala el informe. ... Hoteleros, para impedir la trata de personas y el turismo sexual en el país, .... Las autoridades de Costa Rica arrestaron el martes a dos mujeres como ...

Edificación herediana.Patrimonio denunciará demolición de casona. Actualizado el 18 de mayo de 2010 a las 12:00 am

http://www.nacion.com/ocio/artes/Patrimonio-denunciara-demolicion-casona_0_1123087802.html). 
Documentación sobre la polémica del nuevo edificio para la Asamblea Legislativa. http://www.icomoscr.org/ content/index.php?option=com_content\&view=article\&id=320:asamblea\&catid=49:defensas\&Itemid=84 .

Remodelación del Gran Hotel Costa Rica desató críticas ciudadanas. Actualizado el 06 de junio de 2017 a las 11:00 am. Costarricenses y especialistas en arquitectura consideran drástico el cambio en la fachada del inmueble. Patrimonio asegura que obras conservan el tejido histórico de la estructura http://www.nacion.com/vivir/arquitectura/Remodelacion-Gran-Hotel-Costa-Rica_0_1638036268.html

Estudio Multidisciplinario: aproximaciones al megaproyecto hidroeléctrico el Diquís). http://kioscosambientales.ucr.ac.cr/documentos/EstudioDiquis.pdf.

\section{Notas}

1 Este artículo se basa en una primera versión de la ponencia inédita titulada “Matrimonio o divorcio? otras alternativas en la relación turismo y patrimonio cultural”, que la autora presentó en el eje temático Sociedad, cultura y turismo, en el marco del I Congreso Internacional de Investigaciones en Turismo, evento organizado por la Facultad de Administración de Empresas Turísticas y Hoteleras de la Universidad del Externado, Colombia. El Congreso se realizó del 22 al 24 de octubre del 2014 en la sede de esa Universidad en Bogotá.

2 La colocación en la jerga lexicológica es una unidad fraseológica, en la que se combinan al menos dos palabras que frecuentemente aparecen juntas. Por ejemplo, sal y pimienta, marido y mujer.

3 Aunque el propósito que lleva a producir este texto parece muy simple -he de confesar que como gestora cultural y docente es parte de mi cotidianeidad- la tarea no fue fácil, pues debemos enfrentar cuestiones éticas y sentimientos de impotencia ante realidades locales de comunidades, en contextos de limitaciones de diversa índole, donde ellas deben tomar el control.

4 Tanto entre los académicos/as que estudiante este tema, como entre las personas portadoras de bienes o habitantes de sitios patrimoniales, que hay una distancia entre el discurso hablado o escrito y la ejecución. Esto es común en los discursos de algunos políticos que prometen y no realizan. En Costa Rica, el turismo se ha posesionado de la economía nacional y es frecuente que los candidatos/as a puestos del gobierno local (municipios) o nacional, incluyan la creación de más empresas de turismo rural comunitario, sin tomar en cuenta los factores administrativos y de diversa índole, que influyen en el buen logro de esta meta.

5 Entre las consultas cfr. Arthur Asa Berger, Margarita Barreto, Dean Mac Cannel, Noel Salazar, Mónica Rotman, Agustín Santana, Alessandro Simonicca, J. Nogués-Pedregal, entre otros.

6 Entre ellas: Hernández-López, J.J; M. Rotman y A.N. González de Castells (Editores) 2010. Patrimonio y Cultura en América Latina: nuevas vinculaciones con el estado, el turismo y sus perspectivas actuales (Mesa del II Congreso Latinoamericano de Antropología, UCR). México: Acento Editores; Osorio, J. y E. Rozo (Editores).2013. Turismo y Cultura. Retos y perspectivas en América Latina. Universidad del Externado. Bogotá: Colombia (Mesa del 54 Congreso de Americanistas, U Viena); López Morales, F.J. y F. Vidargas (editores). 2015. Encuentro Internacional. Usos del patrimonio: Nuevos escenarios. México-Guanajuato: INAH-Secretaria de Cultura-Universidad de Guanajuato.; Oechemichen Bazán,C.2013. enfoques antropológicos sobre el turismo contemporáneo, México:UNAM; Chang Vargas, G (Editora). 2015. Memoria del I Congreso Iberoamericano sobre Patrimonio Cultural (2010). San José: UCR.

7 Desde la Declaración de los Derechos Humanos, hasta otros documentos específicos, sobre todo las relacionadas con el ambiente, como Cumbre de Río y la Agenda 21.

8 Esta Carta fue adoptada en la Asamblea General de ICOMOS, realizada en México, en 1999 y señala la misión y foco del Comité Internacional de Turismo Cultural de ese organismo.

$9 \quad$ El contexto varía según la disciplina, por mencionar algunos, si es análisis estructural, se parte del contexto de la frase u oración desde la perspectiva lingüística; si es el análisis crítico del discurso, esto implica un acercamiento interdisciplinario (lingüística, antropología, sociología, historia).

10 La autora de esta comunicación es miembro de ICOMOS de Costa Rica y del Comité Internacional de Patrimonio Cultural Inmaterial (ICICH) de ICOMOS.

11 Ortiz aclara que "... no consiste solamente en adquirir una distinta cultura, que es lo que en rigor indica la voz angloamericana acculturation, sino que el proceso implica también la pérdida o desarraigo de la cultura precedente, lo que pudiera decirse una parcial desculturación y, además significa la consiguiente creación de nuevos de nuevos fenómenos culturales que pudieran denominarse neoculturación" (Ortiz, 1983:90).

12 Nos referimos a individuos que abusan sexualmente. Sin embargo, el anáilsis de Ulrich Beck, se puede aplicar a múltiples sectores, como otro tipo de relaciones de riesgo con grupos sociales cuyo proyecto tiene intereses antagónicos o con distintas prioridades. En la llamada sociedad del riesgo, hay nuevos desafíos por mantener el control de un proyecto.

13 Pratz señala que este puede a) constituirse como un producto turístico per se, capaz de integrar un motivo de compra autónomo; b): puede presentarse asociado a un producto turístico integrado (a un "paquete"); c) puede constituirse en un valor añadido para varios destinos turísticos, que no tienen al patrimonio como principal atractivo.

14 Tomado de World Bank, 1999. Culture Counts: Financing, Resources, and the Economics of Culture in Sustainable Development. Proceedings of the Conference, Washington, D.C.

15 Se ha formado una red latinoamericana para tratar asuntos sobre la deuda, el desarrollo y derechos con grandes entidades financieras, como bancos como el Banco Mundial, el FMI,entre otros. https://www.latindadd.org/2015/10/03/para-que-han-servido-el-fmi-y-e

16 El inventario se realizó como parte del programa del curso "Patrimonio Cultural y Turismo", impartido por la autora de este artículo, a estudiantes del Bachillerato en Antropología, Universidad de Costa Rica, 2006. 
17 Estas observaciones están en notas de campo y en reportes de trabajos de los estudiantes del curso Antropología del Turismo, impartido en la Escuela de Antropología, Universidad de Costa Rica, segundo semestre de los años 2010,2012 y 2014.

18 Observaciones del 2010, como parte de una investigación de la autora titulada "Imaginarios turísticos y transformaciones del patrimonio cultural indígena" (inédita), inscrita en el Doctorado en Estudios de la Sociedad y la Cultura de la Universidad de Costa Rica.

19 En el artículo $5^{\circ}$, expresa la necesidad de que estos cumplan una función útil a la sociedad, pero tomando en cuenta la evolución de usos y costumbres.

20 Es el caso de un debate actual en Costa Rica, del pueblo indígena brunca, en relación con el Juego de los Diablitos y el tipo de máscaras que se deben usar, entre otros puntos de discrepancia de organizaciones comunales. No amplío la información, pues no tengo autorización de las fuentes comunales de divulgar detalles, que se espera se resuelvan a nivel interno, en un corto plazo y sin mediación de entidades foráneas.

21 Como lo señala el principio 4.2 de la Carta.

22 Por ejemplo, realizar estudios de impacto ambiental y sociocultural tanto de las acciones de la naturaleza (que muchas son impredecibles), como de la mente y la mano humana.

$23 \mathrm{Al}$ respecto, Luis Guillermo Solís, Presidente de la República, comentó: "Vamos a darle mucho más rigor a una zona que estaba necesitando de nuevos incentivos para desarrollo turístico.../...Esta declaratoria de la UNESCO es vital para nuestra historia e identidad nacional" (La Nación, 23 de junio, 2014). Se espera que tras esas palabras no se mantenga el proyecto del aeropuerto, que si bien acarrearía la llegada de miles de turistas, el impacto del ruido y el aceite de los aviones, sería negativo sobre las esferas, los humedales y el paisaje cultural de esa zona.

24 Fuentes: Reunión en el Centro de Patrimonio Cultural del Ministerio de Cultura, con la participación de funcionarios de esa institución y miembros de organizaciones de boyeros, San José, sábado 21 de junio, 2014 y entrevista a boyeros en el Sesteo, previo al Desfile Nacional de Boyeros, en San José, sábado 28 de noviembre, 2015.

25 Se refiere a costumbres, fiestas, gastronomía, vestuario, celebraciones y al folklore en general.

26 Entre ellos, los museos comunitarios de Curré y Boruca, la Finca Educativa de Suretka, las mujeres de cacao de Talamanca, la casa de cultura de Palenque Margarita, la Asociación cultural ngöbegue.

27 Como los bruncas, bribris, teribes o térrabas, malecus, ngöbes, cabécares y huetares.

28 El artículo "Los efectos del turismo en las culturas indígenas de América Latina", cuyo autor es Xerardo Pereiro, reúne una serie de casos de efectos e impactos sobre estos pueblos.

29 En relación con proyectos en territorios indígenas, el artículo 6, del Convenio 169 de la Organización Mundial del Trabajo, OIT, estipula el derecho de los pueblos a la consulta previa e informada.

30 Los países pequeños como Costa Rica, no están exentos de caer en ese peligro, pues a pequeña escala, siempre hay alguien que sueña con remedar producciones atractivas, pasando por alto el significado de los valores patrimoniales, pero debemos esperar a que se visibilicen los efectos de proyectos y con datos concretos, tratarlos en otro artículo.

31 En Costa Rica, debido al auge del ecoturismo en las últimas tres décadas, hay diversos niveles para los actores del grupo de intermediarios del turismo. El turismo cultural es incipiente, pero podemos mencionar la labor de la UNED, que produce material didáctico sobre distintos aspectos del turismo, incluyendo el acervo turístico y cultural de las regiones del país. El Museo Nacional ha realizado una labor con miembros de organizaciones locales, que participan como guías en los sitios arqueológicos. 